Blaž Istenič

UDK 81'366.573:81'362

Študent Filozofske fakultete, Univerza v Ljubljani

Slovenija

blazistenic1@gmail.com
DOI: 10.4312/vestnik.11.49-64

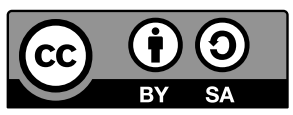

\title{
NEKAJ OPOMB K PRISLOVNODOLOČILNEM TRPNIŠKEM VRŠILCU DEJANJA V SLOVENŠČINI S POGLEDOM NA FRANCOŠČINO IN RUŠČINO
}

UVOD

V sodobnem jezikoslovju je glagolski način pogosto pojmovan kot oblika diateze. Slednja predstavlja »različne ubeseditvene zmožnosti oz. različne stavčnočlenske izraženosti iste pomenske podstave ( $\mathrm{tj}$. povedja in udeležencev) in z ohranitvijo istega sporočilnega smisla« (Žele 2010a: 129). Toporišič (2004: 502) govori o postavljanju udeležencev in povedja »na bolj ali manj ugledna mesta«.

Trpnik je (kot opisujejo Hamma et al. 2017: 1) običajno opredeljen kot rezultat pretvorbe, ki preuredi nevtralni red delovalnikov. Gre za neke vrste »tematizacijo«, kjer predmet prevzame položaj slovničnega osebka, slednji je v novi povedi običajno fakultativen. Toporišič (2004: 358) tvornik/aktiv ${ }^{1}$ in trpnik/pasiv loči tako, da je pri prvem »osebek tudi (iz)vršilec dejanja in nosilec stanja, pri drugem pa je osebek od dejanja prizadeti«.

V članku bomo prevzeli definicijo, ki jo za francoščino med drugim zagovarja Lamiroy (1993). Povezana je s Tesnièrjevim pojmovanjem »recesivne diateze« (diathèse récessive), ki se za razliko od zgoraj opisane »tematizacije« osredotoči na osebek, ne na predmet (ibid.: 59). Gre za récession actancielle ${ }^{2}$ (kar bi lahko prevedli kot umik delovalnika), kjer gre za zmanjšanje števila argumentov; v primeru trpnika gre za površinski umik vršilca, glagolska oblika pa je spremenjena ali s trpnim deležnikom ali z obliko povratnega glagola. Prejšnji predmet, če obstaja, običajno zasede osebkovo mesto (ibid. 62). Lamiroy (ibid.: 56-63) poudarja, da je zdaj pri trpniku ključna možnost predstavitve situacije brez opredelitve vršilca dejanja (posledica tega je večja vloga (prejšnjega) predmeta oz. dejanja samega). To tudi pojasni, zakaj velika večina trpniških stavkov ne izraža vršilca dejanja. Poleg tega lahko tako kot trpne opredelimo tudi brezosebkovne trpnike, kot je slovenski Išče se Uř̌o Plut (cf. razdelek 2.1), saj je, kot rečeno, za nas

1 V članku bomo uporabljali izraza tvornik in trpnik.

2 Seveda je bil tudi trpnik kot récession actancielle deležen kritik (cf. Muller 2000, Di Sciullo 1997); nam bo definicija služila zlasti kot določilo, katere oblike uvrstiti med trpne. 
pomemben predvsem umik vršilca, dogajanje s predmetom pa je drugotno, ni nujno, da se zgodi dekavzacija ${ }^{3}$. Pri brezosebkovnem trpniku s trpnim deležnikom, npr. Na vprašanje je bilo odgovorjeno, se slednje niti ne bi moglo zgoditi, saj je glagol neprehoden že $\mathrm{v}$ tvornem stavku.

Tu lahko omenimo še delo jezikoslovcev Leningrajske tipološke šole, kjer je pomembna zlasti vloga Holodoviča (npr. 1974) in Hrakovskega (npr. 1978). V tej šoli, ki se je vseskozi precej posvečala glagolskemu načinu, diateza pomeni (Kulikov 2010: 369-71) vzorec prenašanja pomenskih udeležencev (torej udeleženskih vlog, npr. vršilca dejanja, prizadetega itd.) na slovnične odnose (osebek, premi predmet itd.), glagolski način pa je na podlagi tega definiran kot regularno kodiranje diateze s pomočjo glagolske morfologije, npr. v eni od možnosti v slovenščini z glagolom biti in trpnim deležnikom. Pri trpniku gre za podobno pojmovanje kot pri naši definiciji, saj je vršilec degradiran ali pa je povsem odstranjen ( $c f$. Kulikov 2010).

Čeprav Orešnik (2015: 60) opozarja, da imajo trpniki glede na jezik predvsem wittgensteinovske »družinske podobnosti« ( $c f$. Wittgenstein 2016: 277 seq., $P U$ §§ 66-67), komaj pa skupnega imenovalca, lahko na začetku povemo, da gre pri trpnikih pri obravnavanih jezikih za dokaj sorodne sheme. Povsod bomo ločili po dve glavni skupini trpnikov (prvo s trpnimi deležniki, drugo z oblikami povratnih glagolov); različico tovrstne delitve običajno sprejemajo tudi ostala jezikoslovna dela.

V nadaljevanju bo namen članka predstaviti tvorbo ter rabo trpnika v slovenščini, francoščini in ruščini ter podrobneje opozoriti na vprašanja in možnosti površinskega izražanja vršilca dejanja v teh konstrukcijah.

\section{2}

\section{SLOVENŠČINA}

V slovenščini se trpnik klasično deli na dve obliki - prvo z deležnikom na - $n /-t$ in drugo s se. Prva se rabi v vseh glagolskih osebah, druga pa domala le v tretjih (Orešnik 2007: 33). Kljub temu Čibej in Orel Kos (2015: 249) za pravna besedila ugotavljata, da je oblika na se celo nekoliko pogostejša.

\subsection{Tvorba in raba trpnika v slovenščini}

Toporišič (2004: 354) omejuje $\mathrm{v}$ trpnik pretvorljive glagole na direktno prehodne z nepredložnim dopolnilom $\mathrm{v}$ tožilniku, pri razmerju tvornika in trpnika pa gre pri njem (ibid.: 358) za pretvorbo, kjer se besedna zveza, ki je bila osebek tvornega stavka, v trpnem opusti ali postane prislovno določilo vršilca glagolskega dejanja, tista, ki je bila

3 V izvirniku je uporabljen glagol détransitiver: narediti glagol neprehoden (iz prehodnega). 
prej predmet tvornega stavka, pa je zdaj osebek; glagolska oblika se zamenja s preteklim trpnim deležnikom ali pa se doda se.

Tako pojmovanje, kot že nakazano, po zgoraj navedenih kriterijih ni ustrezno. Poleg tega, da sta tvornik in trpnik v veliki večini primerov zamenljiva le teoretično in v metalingvističnih kontekstih ( $c f$. Hamma et al. 2017, Lamiroy 1993: 55 seqq.), tako pojmovanje iz vrst trpnikov izključuje nekatere oblike, ki so po našem mnenju evidentno trpne (kot rečeno, je naš glavni kriterij umik vršilca) in prisotne tudi v standardnem/knjižnem jeziku. Gre za primere (tu bomo prevzeli terminologijo iz Orešnik 2015: 60) brezosebkovnega trpnika s trpnim deležnikom (npr. [J]e bilo na sporno pravno vprašanje s strani Vrhovnega sodišča že odgovorjeno ..., tudi Govorjeno je bilo o človekovih pravicah), brezosebkovnega trpnika na se (Išče se Uršo Plut, tudi Namreč zadevno cesto se uporablja tudi pri sečnji gozda ob tej cesti) ter trpnika na se neprehodnih glagolov (Veliko se je plesalo, tudi $V$ nesrečnem mestu se je umiralo na najbolj žalosten in surov način).

Sama raba trpnika je bila sicer v slovenskih normativnih delih pogosto kritizirana ${ }^{4}$ kot »neljudska« in izvirajoča iz tujih jezikov; tudi v strokovnih, poljudnih ali znanstvenih besedilih (kjer naj bi bil običajnejši) da ga »ni dobro preveč uporabljati« (Toporišič 2004: 359).

Logar et al. (2015: 241) v korpusni analizi ugotavljajo, da je sicer pojavnost trpnika (analizirajo le tistega na $-n /-t$ ) večja v strokovnih besedilih (ki jih zajema Kas - korpus akademske slovenščine) kot v običajnih (zajetih v splošni korpus Kres): splošno razmerje je 1,32 : $1 \mathrm{v}$ prid korpusu akademskih besedil, kar je opazna, a ne izjemna razlika, nekatere trpniške oblike so v korpusu Kres celo pogostejše (konkretno tiste v prihodnjiku, pogojniku in velelniku).

Kot rečeno, smo, sledeč Orešniku (2015: 60), trpnik na se razdelili na običajni trpnik na se (Išče se Urša Plut), brezosebkovni trpnik na se (Išče se Uršo Plut) in trpnik na se neprehodnih glagolov (Veliko se je plesalo). Nasploh je vprašanje klasifikacije glagolov (ne samo trpnih) s prostim morfemom se precej zapleteno; v slovenskem jezikoslovju so bile predstavljene številne razdelitve; povzema jih Tomišić (2011). Trpnik je le ena od možnosti, ki jih izražajo glagoli s se (cf. ibid.: 156-178), najbolj očiten (in jasno netrpnški) je pomen, ki so ga slovnice do Toporišiča običajno uvrščale kot medij ${ }^{6}$. Prav nejasnosti zaradi večpomenskosti oblik na se so med razlogi za dvome glede (ne)uvrščanja tega trpnika.

V normativnih delih so kritike že od Breznika naprej letele zlasti na omenjeni brezosebkovni trpnik na se, ki naj bi bil rezultat tujega vpliva ( $c f$. Breznik 1934: 139, kjer govori o »italijanski posebnosti«), a nasprotna stran opozarja na možno dvoumnost

4 Za povzetka obravnavanja trpnika v slovenskih jeziko(slov)nih delih cf. Šek Mertük 2013 in Leskovec 2016.

5 Za značilnosti rabe tovrstnih zgradb $c f$. Uhlik in Žele 2018: 103-105.

6 Medij oz. srednjik je eksplicitno prisoten npr. v stari grščini, od koder navajamo tudi običajno definicijo, da »izraža dejanje, pri katerem je vršilec dejanja, ki ga izraža stavčni osebek, hkrati tudi (posredno ali neposredno) predmet dejanja.« (Babič 2015: 182). V slovenščini, kot navaja avtor, se takšno razmerje izraža s povratnimi glagoli, npr. umivam se. 
običajnega trpnika na se, saj v (znanem) primeru Išče se Urša Plut ni jasno, ali Uršo Plut iščejo drugi ali se sama; pri brezosebkovni različici (torej Išče se Uršo Plut) te dileme ni. Danes je odnos do teh oblik pogosto manj kritičen ( $c f$. npr. Dobrovoljc 2015).

\subsection{Trpniški vršilec dejanja v slovenščini}

V slovenščini po Toporišiču (2004: 358) v trpniku vršilec glagolskega dejanja »namesto da bi bil osebek tvornega stavka, postane v najboljšem primeru prislovno določilo vršilca ali pa je sploh izpuščen«; izpustimo ga, kadar »ni važen ali pa ga nočemo ali ne moremo ugotoviti«.

Že Bohorič je v Zimskih uricah, prvi slovnici slovenskega jezika, navedel možnost izražanja vršilca dejanja (torej t. i. dolgi trpnik) tako pri trpniku na -n/-t kot tistem na se (Šek Mertük 2013: 137). Enako je bilo tudi pri Pohlinu v prvi izdaji slovnice, v drugi pa je zveze s predlogom od z neživim osebkom prišteval kar k tvorniku. Z Vodnikom se je začelo (zaradi podobnosti z nemško obliko) dolgo zavračanje zvez s predlogom od z rodilnikom (ibid.: 138 seq.); kritika se je jasneje prekinila šele s t. i. Slovnico štirih (1954). Še v 20. stoletju so se pojavljali glasovi, da »slovenščina ravno tega popolnega trpnika ne ljubi« (Jesenovec 1965: 95) in, kot je zapisal Breznik v slovnici iz leta 1934, naj trpnik uporabljamo »le tedaj, če ne govorimo o povzročitelju dejanja« (Breznik 1934: 138).

Občutno redkejšo rabo dolgega trpnika (vsaj kar se tiče standarnega jezika) med redkimi raziskavami, ki to omenjajo, potrjujeta tudi Čibej in Orel Kos (2015), ki sicer ugotavljata, da je trpnik v slovenščini precej pogosteje rabljen v strokovnih (v njunih primerih pravnih) besedilih kot $\mathrm{v}$ leposlovju. Primerjata prevode iz angleščine v slovenščino in švedščino in opažata še zlasti veliko razliko pri t. i. dolgem trpniku, kjer je prisoten vršilec dejanja: angleški dolgi trpni stavki iz pravnih besedil v slovenščino so bili v skoraj 75 odstotkih prevedeni s tvornikom, pri literarnih delih pa je bilo takih primerov skoraj 93 odstotkov. Razlog naj bi bil po mnenju avtorjev možnost izražanja iste funkcije s pomočjo besednega reda, ki je v slovenščini fleksibilnejši, tako da je lahko vršilec dejanja uvrščen na konec stavka brez skladenjskih sprememb (ibid.: 249).

Kot edina možnost za uvajanje vršilca dejanja je v $S S$ naveden predlog od z rodilnikom; omenjen je še predlog po s samostalnikom v mestniku, ki je izrecno označen za napačnega (Toporišič 2004: 358).

Tega primata predloga $o d$ sicer podatki ne potrjujejo. Iskra (2013: 81) ob robu svoje raziskave, temelječe na gradivu časnika Delo, ugotavlja, da vršilec dejanja ni bil »niti enkrat uveden s predpisanim predlogom $o d$, ampak so ga pisci raje uvedli s predlogoma $s$ in s strani«. Leskovec (2016: 11) navaja, da primerov trpnika z izraženim vršilcem dejanja v svoji analizi časopisov Dela in Dnevnika sploh ni našla.

Prav predložna zveza s strani je zanimiv primer. Ne navaja je nobena od navedenih slovnic, če pregledamo pretekle trpne deležnike, ki se najpogosteje pojavljajo eno mesto 
pred njo v korpusih Kres in Gigafida 2.0, pa lahko sklepamo, da je lastna zlasti publicističnim in pravnim besedilom (npr. primeri tipa STA umika vest /.../, ker je bil komentar popravljen s strani Večera in [N]aročnik navaja, da so bili vsi dokumenti podpisani s strani pooblaščenih oseb). Tudi v korpusu Kres, ki je glede izvora besedil uravnotežen (Erjavec in Logar Berginc 2012), so namreč deležniki, ki se največkrat pojavljajo na mestu pred s strani, naslednji: potrjen, podpisan, vložen, sofinanciran, financiran, izdan. Odstotek pojavitev deležnikov skupaj s predložno zvezo s strani je sicer glede na število njihovih ostalih pojavitev povečini majhen (običajno nekaj odstoten), a npr. pri sofinanciran s strani znaša celo 17 \% vseh pojavitev (25 od sicer skupaj le 147 v korpusu Kres; npr. Projekt je sofinanciran s strani Evropskega sklada za regionalni razvoj (ESRR)), a so si vse pojavitve izjemno podobne, kar kaže, da gre pri tem konkretnem deležniku za ustaljeno rabo zlasti (evropskih) institucij; poleg tega prej izražajo stanje. Dobrovoljc (2017) sicer navaja terminologinje, ki opažajo, da »v pravnem jeziku tudi zveza $s$ strani dobiva nezaznamovan pomen«, kar kaže, da je vsaj v nekaterih kontekstih že prevzela vlogo izražanja vršilca dejanja predlogu od.

Pri trpniku na se se običajno ( $c f$. Toporišič 2004: 503) navaja, da izraža splošnega vršilca, zaradi česar bi pričakovali njegovo neizraženost s prislovnim določilom (čeprav je Bohorič že v Zimskih uricah navedel možnost njegovega izražanja (Šek Mertuk 2013: 137)), kar v veliki meri drži, a ne popolnoma, saj v jeziku najdemo primere, kot sta (običajna trpnika na se) Doplačila po ceniku se plačajo na blagajni s strani člana kluba in Cesta se uporablja s strani udeležencev v prometu, ki niso lastniki zemljišča ..., kjer torej spet srečamo predložno zvezo s strani. Izraženega prislovnodoločilnega vršilca dejanja na spletu sicer pri brezosebkovnem trpniku na se in trpniku neprehodnih glagolov na se nismo našli, kar kaže na še večjo redkost.

Neizražanje eksplicitnega vršilca dejanja je seveda pri vseh oblikah trpnika povezano s komunikacijsko funkcijo, saj (npr. po Testelcu (2001: 411)) pomembno vlogo pri trpniku igra prav to, da je sporočilo oz. dejanje v ospredju, vršilec pa je potisnjen v ozadje. To kažejo tudi podatki iz drugih jezikov, saj nekateri (npr. arabščina, kot navaja Lamiroy 1993: 63) tovrstnega izražanja vršilca dejanja sploh ne omogočajo.

\section{3}

\section{FRANCOŠČINA}

Francoščina ima po klasičnem pojmovanju (npr. v Riegel et al. 2009;) eno »pravo« obliko trpnika (t. i. passif périphrastique, sestavljen iz oblik preteklega deležnika). Gaatone (1993) podrobneje razlikuje dve obliki, ki sta si zelo blizu, saj gre pri eni za običajni trpnik (primer je npr. Une enquête a été menée (par les autorités compétentes) 'Preiskava je bila vódena (s strani pristojnih oblasti)'), pri drugi pa za njegovo neosebno obliko (npr. Il a été mené une enquête (par les autorités compétentes) 'Vódeno je bilo preiskavo (s strani pristojnih oblasti)'). Druga običajno navajana vrsta trpnika je sestavljena iz oblik 
povratnih glagolov, trpni pomen pa (lahko) izražajo tudi npr. konstrukcije z glagoli se faire, se voir, se laisser, npr. Ils se sont fait cambrioler 'Pri njih je bilo vlomljeno'. Te Le Bellec (2014) klasificira kot tretjo obliko trpnika, lahko pa dodamo, da pri njih lahko izrazimo tudi prislovnodoločilni vršilec dejanja (Elle s'est fait agresser par Sam 'Napadena je bila od Sama'). Mi bomo v razmišljanjih sledili Lamiroy (1993), ki ločuje dve trpniški obliki, torej passif périphrastique in trpnik iz oblik povratnih glagolov (ter ustrezajoče neosebne oblike).

\subsection{Tvorba in raba trpnika $v$ francoščini}

$\mathrm{V}$ passif périphrastique je $\mathrm{v}$ francoščini pretvorljiva velika večina (tvornih) povedi $\mathrm{s}$ premim predmetom. Po Riegel et al. 2009: 730 (klasično pojmovanje, blizu Toporišičevemu za sln.) ga določajo naslednje značilnosti: predmet tvorne povedi je postal osebek; glagol v preteklem deležniku se sprega s pomožnikom être 'biti' in se postavi v čas in naklon, v katerih je spregana oblika glagola v tvorniku; osebek tvorne povedi je lahko v trpni izražen kot prislovno določilo (točneje poimenovan complément d'agent ${ }^{7}$ ), uvedeno s predlogoma par ali de; osebek in predmet tvorne povedi se zamenjata, a ohranita svoji udeleženski vlogi.

Na splošno so v trpnik pretvorljive le t. i. povedi SVO (osebek - glagol - predmet), čeprav v trpniku ne morejo nastopati frazni glagoli in nekateri prehodni glagoli v vseh ali določenih pomenih (mdr. avoir 'imeti' in mesurer 'meriti, biti velik' v slednjem pomenu, *Deux mètres trente sont mesurés par le géant '*Dva metra trideset sta merjena od velikana'). V trpniku pa lahko nastopajo nekateri glagoli z nepremim predmetom (npr. répondre à 'odgovoriti na'); gre za neosebne konstrukcije (npr. Il sera répondu à chaque lettre 'Odgovorjeno bo na vsako pismo') ali glagole, ki lahko v trpniku (zastarelo) nastopajo v knjižnem jeziku (npr. z glagolom obéir à 'ubogati (nekoga)'). Nekateri glagoli pa se uporabljajo le v trpniku (npr. réputer 'imeti za', Les enfants nés de l'union d'un citoyen avec une étrangère étaient réputés bâtards 'Otroke, ki so bili rojeni iz razmerja med državljanom in tujko, so imeli za pankrte' (povzeto po ibid.: 731 seqq.).

$\mathrm{V}$ francoščini obstajajo konstrukcije, ki so zelo podobne slovenskim se-zgradbam (torej tvorjene z oblikami povratnih glagolov, npr. Ce sport se pratique en plein air ' $\mathrm{Ta}$ šport se izvaja na prostem'), a jih normativne slovnice povečini označujejo le kot konstrukcije, ki so trpniku blizu po pomenu, ne pa tudi formalno trpne (cf. Riegel et al. 2009: 742; v svoji monografiji Gaatone (1998: 9-10) kot formalna kazalnika trpnika navaja sekvenci être + pretekli deležnik in predlog par s prislovnim določilom), prav zaradi

7 V francoščini se za aktanta/delovalnika, ki je v trpnih povedih izražen s prislovnim določilom, uporablja izraz complément d'agent, česar pa ne smemo, kot opozarja tudi Gaatone (1998: 176), jemati preveč dobesedno, torej da gre z vsakem primeru za striktnega vršilca dejanja. Najpreprostejša definicija je, da gre preprosto za prvi argument glagolskega leksema (čeprav tudi taka definicija povzroči številne zagate, cf. ibid.: 186). V članku bomo za complément d'agent uporabljali poimenovanje (prislovnodoločilni) trpniški vršilec dejanja. 
oblik, iz katerih so sestavljene. Tudi v francoščini obstaja brezosebkovni trpnik z oblikami povratnih glagolov (npr. Lagae (2002) navaja Il se construit beaucoup de nouveaux immeubles dans le quartier ' $\mathrm{V}$ tej četrti se gradi veliko novih zgradb').

Zanimiva je opazka Lamiroy (1993: 70), ki sicer leti na primerjavo med francoščino, italijanščino in španščino, a je po našem mnenju relevantna tudi za slovenščino: po njenem ta jezika (tudi brezosebkovne) oblike s povratnimi glagoli veliko uporabljata, ker za razliko od francoščine nista razvili neosebnega izražanja z on (npr. On a tout essayé 'Vse smo poskusili/Vse se je poskusilo').

\subsection{Trpniški vršilec dejanja $\mathbf{v}$ francoščini}

Kot v slovenščini je tudi v francoščini velika večina trpnih povedi brez izraženega vršilca dejanja (Riegel et al. 2009: 738; Attal (1985) navaja število, ki kaže na to, da je več kot dve tretjini trpnikov brez izraženega vršilca dejanja, Hamma (2017: 313) pa za govorjeni jezik na podlagi podatkov iz govornega korpusa govori kar o okoli devetdesetih odstotkih krajših trpnikov), ki je torej glede površinskega izražanja fakultativen, čeprav nekateri (cf. Yannick Mathieu 1993, Grevisse 2011: 400) navajajo primere, v katerih naj bi bil obvezen. Nekaj primerov, npr. neustreznost povedi ?Ce bâtiment a été construit '(Ta) stavba je bila zgrajena', iz del ostalih raziskovalcev navaja Gaatone (1998: 183 seqq.), a lahko po njegovem večina takih povedi kljub temu postane sprejemljivih ob ustreznih pragmatičnih okoliščinah. V slovnicah (cf. npr. Grevisse 2011: 401-2; Delatour et al. 2004: 106-7) je kot glavni predlog naveden par, poleg njega v nekaterih primerih tudi de.

Kot navajajo Riegel et al. (2009: 734), se je v klasični francoščini 17. in 18. stoletja za uvajanje trpniškega vršilca dejanja najpogosteje uporabljal predlog de, ob njem sporadično tudi à (ostanki danes v besednih zvezah, kot je être mangé aux mites 'biti pojeden od moljev'). Danes prevladuje par, še vedno se uporablja tudi de, a je v povedi, kjer se pojavita oba, kot tisti, ki uvaja vršilca dejanja, interpretiran par. De je zaznamovan, slovnice ga dovoljujejo, ko določilo, ki ga predlog uvaja, ni »pravi« vršilec dejanja; tu gre zlasti za glagole, ki označujejo občutke, spoznavne procese/operacije in lokalizacije (npr. aimer 'ljubiti', connaitre 'poznati', suivre 'slediti', Le disparu était aimé et estimé de tout ceux qui le connaissaient 'Izginuli je bil ljubljen in spoštovan od vseh, ki so ga poznali'), ni ga mogoče uporabiti z dinamičnimi glagoli (povzeto po Riegel et al. 2009: 733-5).

Kar se tiče primerjave pogostnosti rabe predlogov par in de, Gaatone (1998: 194) navaja, da je glagolov (s premim predmetom), ki v trpnih konstrukcijah zahtevajo uporabo predloga de, le okoli 2 odstotka glede na tiste, ki zahtevajo predlog par, prvi je tudi neproduktiven. Če obstajajo konteksti, v katerih se zdi de ustreznejši od par, je prvi na drugi strani izključen iz večine primerov, kjer se uporablja drugi. Ob tem Gaatone navaja, da je le par možen pri omenjeni neosebni obliki trpnika ( $c f$. razdelek 3 ), pa tudi druge 
omejitve uporabe predloga de (cf. Gaatone 1998: 195 seqq. za celotno taksonomijo rabe obeh predlogov).

Gaatone (ibid.: 210) nazadnje ob povzemanju ugotavlja, da je pri samih predlogih par in de podobno kot pri pretvorbi iz trpnika v tvornik: niso namreč vsi stativni glagoli taki, da ne omogočajo pretvorbe $\mathrm{v}$ trpnik, so pa vsi glagoli, ki ne omogočajo pretvorbe $\mathrm{v}$ trpnik, stativni. Pri predlogih par in de pa gre za to, da stativni glagoli, ki dopuščajo trpno rabo (npr. devoir 'morati'), zahtevajo par.

Kar se tiče trpnika na se iz oblik povratnih glagolov, jezikoslovna dela (cf. Mel'čuk in Milićević 2014: 135; Riegel et al. 2009: 742, Lagae 2002, Lamiroy 1993: 67) pogosto navajajo, da pri njih prislovnodoločilnega vršilca dejanja ni mogoče izraziti. Na drugi strani npr. Hamma (2017: 319) navaja (redke) primere, v katerih je (prislovnodoločilni) vršilec dejanja izražen, npr. Le saké se boit chaud par la grande majorité des japonais 'Sake se s strani velike večine Japoncev pije topel'. Pri tem ugotavlja, da je izraženost vršilca dejanja $\mathrm{v}$ teh primerih povezana s splošnostjo, nereferenčnostjo vršilcev.

4 RUŠČINA

V sodobni ruščini literatura običajno (npr. Švedova et al. 1980) loči dve vrsti trpnika, analitično (z dovršnimi glagoli, tvorjeno iz deležnika) in sintetično (s povratnimi oblikami nedovršnih glagolov). Kot navaja Kolomacki ${ }^{8}$ (2009: 54), nekateri (npr. Bondarko) analitično obliko označujejo za »pravi«, »izvorni« trpnik (med drugim poudarjajo večpomenskost postfiska - $c я$ ), sintetična pa naj bi bila drugotna; drugi (npr. Veyrenc) so nasprotnega mnenja (med drugim opozarjajo, da se trpni deležnik ne uporablja v sedanjiku, ki je nezaznamovana, slovarska oblika).

V slovenščini omejitve glede vida niso tako stroge, kar je verjetno povezano tudi z nekoliko drugačnim delovanjem glagolskega vida (npr. pri ponavljanju lahko v slovenščini uporabimo dovršnik, $v$ ruščini izrecno ne). Tako je mogoče v slovenščini obliko na se uporabiti pri glagolih obeh vidov, npr. Z natisnjeno vlogo /.../ se obišče Avtobusno postajo Ljubljana ... in Zelo intenzivno se išče ustrezne gene, $\mathrm{v}$ ruščini pa načeloma le pri nedovršnikih, čeprav raziskave kažejo tudi prisotnost dovršnih oblik (izčrpno stanje raziskav in priporočil povzema Percov 2013).

\subsection{Tvorba in raba trpnika v ruščini}

V ruščini je za prehodne dovršne glagole značilno izražanje trpnika s kratko obliko preteklega trpnega deležnika (Художник написал портрет - Портрет написан

8 cf. Kolomacki 2009: 186 seqq. za kritiko tradicionalnih (površinskih - v generativnem smislu) pristopov k delovalniku pri trpniku. 
художником 'Slikar je naslikal portret' - 'Portret je bil naslikan s strani slikarja'). Pri prehodnih nedovršnikih je trpnik s kratko obliko preteklega trpnega deležnika redek; poleg tega lahko ti glagoli trpnik oblikujejo tudi s kratko obliko sedanjih trpnih deležnikov ${ }^{9}$. Gre zlasti za glagole, ki označujejo razmerja med udeleženci (za podrobno obdelavo teh deležnikov cf. Saj 2015), npr. Николай был уважаем, но не любим в обществе 'Nikolaj je bil spoštovan, a ne priljubljen v družbi', a je ta način knjižen in prav tako redek ter obenem ni mogoč pri vseh glagolih (povzeto po Švedova et al. 1980: 613-615).

Letučij (2011) v poglavju Ruske korpusne slovnice o neosebnih konstrukcijah poudarja, da se trpne oblike v ruščini običajno uporabljajo osebno, obstaja pa razred brezosebkovnih trpnikov, ki se oblikujejo zlasti iz glagolov rekanja, npr. Может быть, это лучшее, что /.../ было сказано о самобытной силе красоты 'Lahko, da je to najboljše, kar je bilo rečeno o samobitni sili lepote'.

Nedovršniki trpnik običajneje izražajo z oblikami povratnih glagolov (dodajanje postfiksa -cя). Tako nastane razmerje med prehodnim nedovršnikom v tvorniku in trpniško konstrukcijo z obliko povratnega glagola (npr. Уборщзица моет поль - Поль моются уборшицей 'Čistilka pomiva tla' - 'Tla so pomivana od čistilke'). Gre zlasti za rabo v 3. osebi ednine, druge oblike so redke (prav tako tudi tovrstna tvorba trpnika pri dovršnih glagolih, čeprav $c f$. Percov 2013). V vseh omenjenih primerih je lahko trpnik izražen tudi s trpnim sedanjim deležnikom, če glagol njegovo tvorbo dopušča (povzeto po Švedova et al. 1980: 613-615). Vinogradov (1986: 493) navaja, da je uporaba trpnika s -cя sicer zelo omejena, Letučij (2014) v poglavju Ruske korpusne slovnice o povratnosti omenja, da gre najpogosteje za glagole »poklicne aktivnosti« (cmроить 'graditi', асфальтировать 'asfaltirati' ipd.).

Sicer Letučij (ibid.) predstavi obširno razdelitev povratnih glagolov (ter podrobneje tistih s trpnimi pomeni); naj omenimo le brezosebkov trpnik (безличный пассив) iz oblik povratnih glagolov, npr. Здесь намекается на то, что автор предыдущей статьи ошибается 'Tu se namiguje na to, da se avtor prejšnjega članka moti'). T. i. modalnega trpnika, kjer gre za doživljalca, ne vršilca dejanja, ne bomo obravnavali.

\subsection{Trpniški vršilec dejanja v ruščini}

Tudi v ruščini je prislovnodoločilni trpniški vršilec dejanja (gre za t. i. косвенное oz. агентивное дополнение) izražen ali ne. Če da, potem je z brezpredložnim orodnikom (npr. Поль моются уборщицей раз в неделю - 'Tla so tedensko pomivana s strani čistilke'). Ponavadi, ne pa izključno, gre za živo (enako kažejo podatki, ki jih navaja Kolomacki 2009: 236). Ti dolgi trpniki so značilnost knjižnega jezika, kratki trpniki so precej pogostejši. Funkcija izraženega vršilca dejanja služi tudi jasnemu izrazu, da gre za trpno

9 Slovenščina termina sedanji trpni deležnik ne pozna, njegov ustreznik je najpogosteje slovenski deležnik na -n, npr. bran : читаемый. 
poved, zlasti pri povratnih glagolih, kjer je sicer pomen trpnosti oslabljen in imajo lahko v nekaterih primerih dvojno (trpno in tvorno) interpretacijo. Odsotnost izražanega vršilca dejanja pa pri dovršnikih (ki trpnik tvorijo s preteklim trpnim deležnikom) pomeni, da pomen stanja prevlada nad pomenom dejanja (Магазин был открыт продавиом в 10 часов - Магазин открыл 'Trgovina je bila ob desetih odprta s strani prodajalca' - 'Trgovina je odprta') (skupaj s primeri povzeto po Švedova et al. 1980: 614-615).

V staroruskem jeziku (stari vzhodni slovanščini), kar je zanimivo za primerjave s slovenščino, se je ob orodniku za izražanje trpnega vršilca dejanja uporabljal predlog om 'od' $\mathrm{z}$ rodilnikom. Poleg tega nekateri navajajo tudi primere izražanja trpnega vršilca dejanja z drugimi skloni (povzeto po ibid.: 231). Že Bondarko in Bulanin (1967: 173) poudarjata, da so dolgi trpniki precej redki.

Ugotovitev Kolomackega (2009: 242 seq.), ki je kljub vsemu v precejšnji meri v skladu z navedbami Švedove et al. (1980: 614-16) ter Bondarka in Bulanina (1967: 178), je, da orodnik služi (predvsem) kot »sredstvo dodatnega poudarka trpnosti v primerih, kjer je to potrebno « in da ni izražen, če je trpnost stavka jasna. ${ }^{10}$

Kar se tiče (orodniškega) izražanja vršilca dejanja pri trpniku iz oblik povratnih glagolov v ruščini, Letučij (2014) navaja, da se redko pojavlja v pogovornem jeziku ali umetniški prozi, pogosteje v publicistiki in znanstveni literaturi, največkrat, ko je neživ (kar se razlikuje od zgoraj navedenega splošnega poudarka, da običajno izraža živo).

Letučij (ibid.) še navaja, da se pri omenjenem brezosebkovnem trpniku iz oblik povratnih glagolov vršilec dejanja običajno ne izraža (čeprav so slovnično pravilni stavki tipa Им объявляется о заключении сделок 'Od njega se sporoča o sklenitvi poslov'), na drugi strani je to pri analitičnem brezosebkovnem trpniku pogosteje (Об этом было объявлено председателем Совета 'То je bilo sporočeno s strani predsednika sovjeta'), čeprav gre večinoma za starejše primere.

\section{5}

\section{ZAKLJUČEK}

Sopostavitev slovenščine, francoščine in ruščine je pokazala, da slovnice in raziskave v vseh treh jezikih navajajo občutno manjšo rabo dolgega trpnika glede na kratki trpnik (npr. Čibej in Orel Kos 2015; Riegel et al. 2009: 738; Švedova et al. 1980: 614-15). To se glede na našo začetno definicijo zdi pričakovano. Poleg tega ob slovenščini (mdr. glede na ugotovitve v Čibej in Orel Kos 2015) tudi francoščina (to v primerjavi z angleščino ugotavljata Mel'čuk in Milićević 2014: 139) preferira rabo tvornika.

Kar se tiče primerjave trpniških oblik, ki so tvorjene z deležniki, in tistih na se, je, kot navajajo tudi jezikoslovna dela (slovenska te možnosti pri oblikah na se običajno

10 Razlago gre po njegovem mnenju iskati zlasti v načelu ekonomičnosti, saj je pogostnost uporabe orodnika največja pri deležnikih na $-M-$, pri katerih ni vedno jasno, ali gre za izražanje trpnika; če je trpnost očitna (npr. pri deležnikih na -H-/-m-), pa običajno dopolnila ne srečamo (Kolomacki 2009: 245). 
sploh ne omenjajo, sami smo našli le nekaj primerov), pri slednjih izražanje prislovnodoločilnega vršilca dejanja redkejše, kar se zdi pričakovano, saj (kot piše Lagae 2002) je pri oblikah na se že vršilec že nekako impliciten, človeški (Lamiroy (1933: 66) piše, da je »arbitraren«), splošen, a je lahko, kot kažejo primeri rabe, tudi zožen.

Hamma (2017: 311 seq.) poudarja pomembno podrobnost: vsaj v govoru (pa tudi v pisnih besedilih) je za odsotnost trpniškega vršilca dejanja pogosto razlog njegova impliciranost, zlasti če gre za npr. (v francoščini) rabo z nedoločnim členom. Navaja primer Un hamster a été soigné par un vétérinaire '(Nek) hrček je bil oskrbljen od (nekega) veterinarja', kjer je v običajni komunikaciji samoumevno, da je bil veterinar tisti, ki je oskrbel hrčka. V običajni komunikaciji izražanje trpniškega vršilca dejanja razumemo predvsem kot neke vrste kontrast, presenetljivo dejstvo, npr. poved La vase a été cassé par Marie 'Vaza je bila razbita s strani Marije' uporabimo, ko hočemo poudariti, da je vazo razbila Marija, ne pa nekdo drug, ki npr. sicer velja za nerodnega in za katerega bi pričakovali, da jo je razbil (povzeto po Hamma 2017: 316-7).

$\mathrm{Ob}$ tem je seveda treba razlikovati tudi samo naravo uporabe trpnika, ki se pri splošnih govorjenih besedilih (na katere se osredotoča Hamma) ali na drugi strani npr. pri pravnih (pisnih) besedilih precej razlikuje. Pri slednjih zaradi njihove narave lahko predpostavimo večjo pogostnost rabe dolgega trpnika; ekonomičnost (ki jo omenja Kolomacki 2009: 245) tam ni na prvem mestu, pomembna je namreč prav natančnost in tudi samoumevno mora biti ubesedeno. Lahko predpostavimo, da so razlogi za slovničarske kritike dolgega trpnika vsaj delno povezani prav z željo, »da ni nobene besede niti preveč niti premalo«, kot sta pred stoletji pisala že Arnauld in Lancelot [1676] 2016: 150).

Seveda so o trpniku potrebne nadaljnje študije (zlasti na korpusnem gradivu in, kot opozarjajo tudi Logar et al. (2016: 243), brez omejitev na rigidno določeno kategorijo), ki bi pokazale popolnejšo sliko njegove rabe (za dober primer $c f$. Kolomacki 2009) - skupaj z osvežitvijo pristopa in opisa trpniškega vršilca dejanja; tudi zato ker dozdajšnji pristopi (gre zlasti za štetje ne prav velikega števila naključnih povedi) niso ustrezni za resnejši opis. Tu lahko samo napotimo na Hamma (2017: 322-23), ki na koncu svojega članka govori o uspešni rehabilitaciji »tega dopolnila, ki ga imajo običajne metalingvistične glose za 'ohlapnega' in drugorazrednega«.

\section{BIBLIOGRAFIJA}

ARNAULD, Antoine/Claude LANCELOT [1676] (2016) Grammaire générale et raisonnée. Pariz: Éditions Allia.

ATTAL, Pierre (1985) Le passif : étude de corpus. L'Information Grammaticale 27, 10 13. <https://www.persee.fr/doc/igram_0222-9838_1985_num_27_1_3396> (dostop 18. 7. 2019). 
BABIČ, Matjaž (2015) Grška slovnica. Ljubljana: Znanstvena založba Filozofske fakultete.

BONDARKO, Aleksandr. V./Lev. L. BULANIN (1967) Russkij glagol. Leningrad: Prosveščenie.

BREZNIK, Anton (1934) Slovenska slovnica za srednje šole. Celje: Družba sv. Mohorja.

CREISSELS, Denis (2001) Remarques sur la notion de passif et l'origine des constructions passives. Linx 45, 71-82.

ČIBEJ, Jaka/Silvana OREL KOS (2015) Slovene and Swedish translation equivalents of the English passive in two discourse types. BREZAR SCHLAMBERGER, Mojca/ David LIMON/ Ana GRUNTAR JERMOL (ur.) Contrastive analysis in discoursestudies and translation. Ljubljana: Znanstvena založba Filozofske fakultete. $<$ https://e-knjige.ff.uni-lj.si/znanstvena-zalozba/catalog/download/20/79/823-1?inline=1> (dostop 18. 7. 2019).

DI SCIULLO, Anna-Maria (1997) Projections and Interface Conditions. Essays on Modularity. New York/Oxford: Oxford University Press.

DOBROVOLJC, Helena (2015) Raba trpne glagolske oblike. Jezikovna svetovalnica, $<$ https://svetovalnica.zrc-sazu.si/topic/944/raba-trpne-glagolske-oblike> (dostop 18. 7. 2019).

DOBROVOLJC, Helena (2017) Ujemanje povedka in priredno zloženega osebka, povezanega $\mathrm{z} » \mathrm{in} \ll / » a \mathrm{li} \ll$ ter uporaba zveze $» \mathrm{~S}$ strani«. Jezikovna svetovalnica, $<$ https://svetovalnica.zrc-sazu.si/topic/2065/ujemanje-povedka-in-priredno-zlo\%C5\%BEenega-osebka-povezanega-z-in-ali-ter-uporaba-zveze-s-strani> (dostop 5. 11. 2019).

ERJAVEC, Tomaž/Nataša LOGAR BERGINC (2012) Referenčni korpusi slovenskega jezika (cc)Gigafida in (cc)KRES. ERJAVEC, Tomaž/Jerneja ŽGANEC GROS (ur.) Zbornik Osme konference Jezikovne tehnologije. Ljubljana: Institut Jožef Stefan. 57-62.

GAATONE, David (1993) Les locutions verbales et les deux passifs du français. Langages 109, 37-52. <https://www.persee.fr/doc/lgge_0458-726x_1993_num_ 27_109_1090>(dostop 19.7. 2019).

GAATONE, David (1998) Le passif en français. Pariz, Bruselj: De Boeck \& Larcier.

GREVISSE, Maurice (2011) Le bon usage. Bruselj: Duculot.

Gigafida 2.0: Korpus Gigafida 2.0. < https://viri.cjvt.si/gigafida/> (dostop 20. 7. 2019).

GOLDEN, Marija (2001) Teorija opisnega jezikoslovja. 1, Skladnja. Ljubljana: Filozofska fakulteta.

GORJANC, Vojko/Darja FIŠER (2013) Korpusna analiza. Ljubljana: Znanstvena založba Filozofske fakultete.

HAMMA, Badreddine (2017) Tentative de classification des " compléments d'agent » dans les phrases passives achevées et dans les énoncés longs à sens passif. Ela. Études de linguistique appliquée 187, 311-324.

HAMMA, Badreddine/Amélie TARDIF/Flora BADIN (2017) Le passif à l'oral. $<$ halshs$-01465258 \mathrm{v} 1>$ (dostop 7. 11. 2019). 
HOLODOVIČ, Aleksander A. (ur.) (1974) Tipologija passivnyh konstrukcij. Diatezy $i$ zalogi. Moskva: Nauka.

HRAKOVSKI, Viktor S. (ur.) (1978) Problemy teorii grammatičeskogo zaloga. Leningrad: Nauka.

ISKRA, Lorena (2015) Spremembe tendenc pri rabi trpnega glagolskega načina v času med drugo polovico 20. stoletja in začetkom 21. stoletja (diplomsko delo). Ljubljana: Filozofska fakulteta.

JESENOVEC, France (1965) Raba trpnika v slovenščini. VURNIK, France (ur.) Jezikovni pogovori. Ljubljana: Cankarjeva založba. 94-9.

Kres: Korpus Kres. < http://www.korpus-kres.net> (dostop 21. 7. 2019).

KOLOMACKI, Dmitrij I. (2009) Distribucija russkih passivnyh form: korpusnoe issledovanie (disertacija). Moskva: Moskovska državna univerza. <https://iling-ran.ru/ kolomatsky/thesis.pdf> (dostop 23. 7. 2019).

KULIKOV, Leonid (2013) Voice Typology. SONG, Jae Jung (ur.) The Oxford Handbook of Linguistic Typology. Oxford: Oxford Press.

LAGAE, Véronique (2002) Le passif pronominal: une forme complémentaire du passif périphrastique? Cahiers Chronos 10.

LAMIROY, Béatrice (1993) Pourquoi il y a deux passifs. Langages 109, 53-72.

LE BELLEC, Christel (2014) La construction passive en 'se faire': une forme concurrente et complémentaire du passif canonique. French Language Studies 24, 203-222.

LESKOVEC, Mojca (2016) Jezikoslovni pogled na trpnik v zgodovini slovenskega jezika. Jezik in slovstvo 1, 3-13.

LETUČIJ, Aleksandr B. (2011) Bezličnost'. Materialy dlja proekta korpusnogo opisanija russkoj grammatiki (http://rusgram.ru). Na pravah rukopisi. Moskva.

LETUČIJ, Aleksandr B. (2014) Vozvratnost'. Materialy dlja proekta korpusnogo opisanija russkoj grammatiki (http://rusgram.ru). Na pravah rukopisi. Moskva.

LOGAR, Nataša/Špela ARHAR HOLDT/Tomaž ERJAVEC (2016) Slovenski strokovni jezik: korpusni opis trpnika. KRŽIŠNIK, Erika/Miran HLADNIK (ur.) Toporišičeva obdobja. Ljubljana: Znanstvena založba Filozofske fakultete. 237-45.

MARUŠIČ, Franc/Rok ŽAUCER (2015) Slovenska slovnica. AHAČIČ, Kozma (ur.) Slovenske slovnice in pravopisi: spletišče slovenskih slovnic in pravopisov od 1584 do danes. Različica 1.0., <https://fran.si/slovnice-in-pravopisi/46/1976-toporisic> (dostop 19. 7. 2019).

MEL'ČUK, Igor/Jasmina MILIĆEVIĆ (2014) Introduction à la linguistique (volume 2). Pariz: Herman Éditeurs.

MULLER, Claude (2000) Le passif processif et ses concurrents. Définition et quelques particularités. SCHØSLER, Lene (ur.) Le passif. Études Romanes 45. København: Museum Tusculanum Press. 49-69.

OREŠNIK, Janez (2007) Slovenski trpnik na se (v naravni skladnji). Slavistična revija $55 / 1-2,31-39$. 
OREŠNIK, Janez (2015) Naravna skladnja. Ljubljana: Slovenska akademija znanosti in umetnosti.

PERCOV, Nikolaj V. (2003) Vozvratnye stradatel'nye formy russkogo glagola v svjazi s problemoj suščestvovanija v morfologiji. Voprosy jazykoznanija 4, 43-71.

RIEGEL, Martin/Jean-Christophe PELLAT/René RIOUL (2009) Grammaire méthodique du français. Četrta izdaja. Pariz: Presses Universitaires de France.

SAJ, Sergej S. (2015) Dejstvitel'noe pričastie nastojaščego vremeni. Materialy dlja proekta korpusnogo opisanija russkoj grammatiki (http://rusgram.ru). Na pravah rukopisi. Moskva.

ŠEK MERTÜK, Polonca (2013) Obdobja preučevanja trpnega glagolskega načina v slovnicah slovenskega jezika (od A. Bohoriča, 1584, do J. Toporišiča, 2004). Časopis za zgodovino in narodopisje 49/1, 133-51.

ŠVEDOVA, Natalija J. (ur.) et al. (1980) Russkaja grammatika. Moskva: Nauka.

TESTELEC, Jakov G. (2001) Vvedenie v obščij sintaksis. Moskva: Rossijskij gosudarstvennyj gumanitarnyj universitet.

TOMIŠIĆ, Mojca (2011) Oprostite, zaspal sem se! Glagoli s se v slovenščini. Maribor: Mednarodna založba Oddelka za slovanske jezike in književnosti, Filozofska fakulteta.

TOPORIŠIČ, Jože (1965) O slovenskih glagolskih načinih. VURNIK, France (ur.) Jezikovni pogovori. Ljubljana: Cankarjeva založba. 100-5.

TOPORIŠIČ, Jože (2004) Slovenska slovnica (SS). Četrta prenovljena in razširjena izdaja, 2. natis. Maribor: Obzorja.

UHLIK, Mladen/Andreja ŽELE (2018) Brezosebne zgradbe v slovenščini: kontrastiva z drugimi južnoslovanskimi jeziki in ruščino. Jezikoslovni zapiski 24/2, 99-112.

VINOGRADOV, Viktor V. (1986) Russkij jazyk. Grammatičeskoe učenie o slove. 3. izdaja. Moskva: Vysšaja škola.

WADE, Terence (2010) A Comprehensive Russian Grammar. Oxford; Malden (Mass.): Wiley-Blackwell.

WITTGENSTEIN, Ludwig (2016) Werkausgabe Band 1: Tractatus logico-philosophicus. Tagebücher 1914-1916. Philosophische Untersuchungen (PU). 22. izdaja. Berlin: Suhrkamp.

YANNICK MATHIEU, Yvette (1993) Quelques passifs avec agent obligatoire. Langages 109, 35-36. <https://www.persee.fr/doc/lgge_0458-726x_1993_ num_27_109_1089> (dostop 23. 7. 2019).

ŽELE, Andreja (2010a) Diateza v slovenščini. Riječ: časopis za filologiju 16/3, 128-152. ŽELE, Andreja (2010b) Elipsa med glagolsko intenco in besedilno koherenco. Slavistična revija 58/1, 117-131. 


\section{POVZETEK}

\section{Nekaj opomb k prislovnodoločilnem trpniškem vršilcu dejanja v slovenščini s pogledom na francoščino in ruščino}

Članek se ukvarja z vprašanjem izražanja trpnika in posebej z možnostmi izražanja trpniškega vršilca dejanja v vlogi prislovnega določila v slovenščini, čemur doda tudi pogleda na isto vprašanje v francoščini in ruščini (povsod glede na standardni oz. knjižni jezik). Najprej so na kratko predstavljeni sodobnejši jezikoslovni pristopi k trpniku (glagolski način kot oblika diateze), potem pa je tematika razdeljena po jezikih. Pri vsakem je najprej orisana klasična delitev trpnih konstrukcij, njihova tvorba in splošne značilnosti. V splošnem sta pri vsakem jeziku obravnavana trpnik $\mathrm{s}$ trpnim deležnikom in trpnik z oblikami povratnih glagolov ter njune brezosebkovne ustreznice. Posebna pozornost je posvečena izražanju vršilca dejanja $v$ teh konstrukcijah in opisu njegove rabe ter predlogov, ki ga uvajajo (slovenščina, francoščina; v ruščini je brezpredložen), pri slovenščini je zlasti izpostavljena vloga predložne zveze $s$ strani. V pisnem jeziku je največja raba trpnika zabeležena v strokovnih besedilih, izražanje trpniškega vršilca dejanja pa je v vseh treh jezikih razmeroma redko, posebej maloštevilni so tovrstni primeri pri trpniku z oblikami povratnih glagolov. Normativne slovnice povečini sicer izražanju vršilca dejanja $\mathrm{v}$ trpnih konstrukcijah niso preveč naklonjene. Področje je v slovenščini slabo raziskano.

Ključne besede: trpnik, pasiv, vršilec dejanja, prislovno določilo, dolgi trpnik, primerjava

\section{ABSTRACT \\ Some remarks on expressing the agent in long passive constructions in Slovenian with a per- spective from French and Russian}

The paper discusses the means of expression of the passive voice and, primarily, of the agent in long passive constructions (i.e. in the role of an adjunct) in Slovenian. The analysis is further developed by perspectives from French and Russian on the same question (regarding the standard varieties of the three languages). First, the paper presents a summary of contemporary approaches to the passive voice (voice as a form of diathesis), followed by a description, structured according to the language, of the types, formation, and general characteristics of these constructions. In general, the passive formed with a participle and the one constructed by means of pronominal verb forms are distinguished and considered for each language (in addition to their impersonal counterparts). Particular attention is paid to the means of expressing the agent, especially to the prepositions used (in Slovenian and French; it is used without a preposition in the Russian language). Special focus is given to the prepositional phrase $s$ strani in Slovenian. In written language, the passive voice is most widely used in the expert literature; the expression of the agent is quite rare in all three 
languages (least often used in the passive constructions with pronominal verb forms) and has been often criticized in (prescriptivist) grammars. As it pertains to the Slovenian language, the topic is under-researched.

Keywords: passive voice, agent, adjunct, long passive, comparison 